\title{
EFEK DEFOLIASI TERHADAP LAJU PERIMBANGAN PERTUMBUHAN TANAMAN UBI JALAR
}

\author{
Edyson Indawan $^{1 \bullet}$, Reza Prakoso Dwi Julianto ${ }^{1}$, Poppy Indri Hastuti ${ }^{2}$ \\ ${ }^{1}$ Program Studi Agroteknologi, Fakultas Pertanian, Universitas Tribhuwana Tunggadewi, Malang, Indonesia; \\ ${ }^{2}$ Program Studi Akutansi, Fakultas Ekonomi, Universitas Tribhuwana Tunggadewi, Malang, Indonesia \\ `Email korespondensi: mankedlht@yahoo.com
}

\begin{abstract}
Sweet potatoes have horizontal leaf growth, so the leaves are piled up and overlapping, therefore pruning or defoliation is necessary. Defoliation is carried out with the aim of reducing the vegetative growth rate, because the vegetative growth rate that is not balanced with generative growth will cause a decrease in the yield of sweet potato tubers. The purpose of this study was to obtain information about the effect of differences in defoliation in three cultivars of sweet potato on yield, as well as to determine the exact level of leaf defoliation of the three cultivars of sweet potato.. Factorial Randomized Design by placing Cultivars as the first factor, (C) included: $C_{1}$ (Beta-2), $C_{2}$ (Kuningan Merah), $C_{3}$ (BIS OP-61-OP-22). The second factor of Defoliated (D), namely : $D_{1}$ (Defoliation $\left.16 \mathrm{WAP}\right), D_{2}$ (Defoliation $\left.12 \mathrm{WAP}\right), D_{3}$ (Defoliation $8 \mathrm{WAP}$ ), with 3 replications. The results showed that: A high RGR value is followed by a large price URL', meaning that the balance of new plant material is related to the ability of plants to carry out photosynthesis. Cultivar value Beta-2 RGR (8-4) $=71 \mathrm{mg} \cdot \mathrm{g}^{-1} \mathrm{day}^{-1}$, Kuningan Merah $U L R^{\prime}(8-12)=65 \mathrm{mg}_{\mathrm{cm}} \mathrm{cm}^{-2}$. BIS OP-61-OP-22 cultivars produce large criteria $(51.22$ tubers/plot$\left.{ }^{1}\right)$ and medium criteria (44.33 tubers.plot $\left.{ }^{-1}\right)$. Beta-2 cultivars produce small criteria (45.56 tubers.plot $\left.{ }^{-1}\right)$. Ratio $R / F$ from BIS OP-61-OP-22 cultivars $R / F>1,5 \pm 2,0$ (high dual-purpose), cultivars Beta-2 and Kuningan Merah, $R / F$ $>3$ (high root production).
\end{abstract}

Keywords: cultivar, defolation, ratio, sweet potato.

Abstrak. Ubi jalar mempunyai pertumbuhan daun secara horizontal, sehingga daun menumpuk dan tumpang tindih oleh karena itu perlu dilakukan pemangkasan atau Defoliasi. Defoliasi dilakukan dengan tujuan untuk mengurangi laju pertumbuhan vegetatif, karena tingkat pertumbuhan vegetatif yang tidak diimbangi oleh pertumbuhan generatif akan menyebabkan penurunan hasil umbi ubi jalar. Tujuan dari penelitian ini adalah untuk memperoleh informasi tentang pengaruh perbedaan defoliasi pada tiga kultivar ubi jalar terhadap hasil, serta menentukan tingkat defoliasi daun yang tepat dari ketiga kultivar ubi jalar. Rancangan digunakan adalah Rancangan Acak Kelompok Faktorial dengan menempatkan kultivar sebagai faktor pertama, (C) meliputi: $\mathrm{C}_{1}$ (Beta-2), $\mathrm{C}_{2}$ (Kuningan Merah), $\mathrm{C}_{3}$ (BIS OP61-OP-22). Faktor kedua defoliasi (D), yaitu: $\mathrm{D}_{1}$ (Defoliasi 16 MST), $\mathrm{D}_{2}$ (Defoliasi $12 \mathrm{MST}$ ), $\mathrm{D}_{3}$ (Defoliasi 8 MST), dengan 3 ulangan. Hasil penelitian menunjukkan bahwa: Harga RGR yang tinggi diikuti oleh nilai ULR yang besar, yang berarti bahwa perimbangan bahan tanaman baru terkait dengan kemampuan tanaman untuk melakukan fotosintesis. Nilai kultivar Beta-2 RGR (8-4) $=71 \mathrm{mg} \cdot \mathrm{g}^{-1} \cdot$ hari $^{-1}$, Kuningan Merah ULR' $(8-12)=65 \mathrm{mg} \cdot \mathrm{cm}^{-2}$. Kultivar BIS OP-61-OP-22 menghasilkan kriteria umbi Besar (51.22 umbi.plot ${ }^{-1}$ ) dan kriteria umbi Sedang (44.33 umbi.plot ${ }^{-1}$ ). Kultivar Beta-2 menghasilkan kriteria umbi Kecil (45.56 umbi.plot ${ }^{-1}$ ). Rasio R/F dari kultivar BIS OP-61-OP-22 R/F > 1,5 $\pm 2,0$ (tujuan ganda tinggi), kultivar Beta-2 dan Kuningan Merah, R/F > 3,0 (produksi akar tinggi).

Kata kunci: defoliasi, kultivar, rasio, ubi jalar.

\section{PENDAHULUAN}

Kementerian Pertanian Republik Indonesia telah menyatakan bahwa tahun 2045 seharusnya sudah menjadi lumbung pangan dunia. Target tersebut akan tercapai melalui program swasembada pangan yang telah digulirkan sejak 2016. Penurunan jumlah produksi tanaman ubi jalar dapat disebabkan oleh teknik budidaya yang dilakukan kurang tepat sehingga produksi tanaman ubi jalar tidak optimal. Salah satu upaya yang dilakukan untuk meningkatkan produksi ubi jalar adalah dengan melakukan defoliasi daun. Budidaya ubi jalar untuk menghasilkan makanan dan pakan secara bersama perlu dikembangkan dan ditingkatkan, tetapi informasi dan praktiknya belum optimal masih terbatas dan perlu dikembangkan. Terhambatnya pertumbuhan umbi diakibatkan oleh pertubuhan vegetatif yang berlebihan (Gibberson, 2011). Tanaman ubi jalar memiliki susunan daun secara horizontal, sehingga daun menumpuk dan tumpang tindih, oleh karena itu perlu untuk dipangkas 
(Rahmiana et al., 2015). Novianti dan Setiawan (2018) bahwa pemangkasan dapat menyebabkan kenaikan bobot segar dan meningkatkan pertumbuhan vegetative, berpengaruh terhadap peningkatan panjang batang, jumlah dan panjang cabang primer, jumlah dan panjang cabang sekunder, serta jumlah stek pucuk ukuran $25 \mathrm{~cm}$. Penelitian Suminarti dan Novriani (2017) menunjukkan bahwa defoliasi mempengaruhi berbagai komponen pertumbuhan: jumlah cabang, jumlah daun, luas daun, dan total umbi segar. Defoliasi pada daun dan batang tanaman ubi jalar dimaksudkan untuk mengurangi laju pertumbuhan vegetative. Pertumbuhan vegetatif yang berlebihan dapat menyebabkan pembentukan umbi menjadi terhambat sehingga akan mempengaruhi produksi umbi. Bagian tajuk tanaman ubi jalar sebagian besar terdiri dari batang dan daun. Daun merupakan tempat dihasilkannya fotosintat, sedangkan tangkai daun dan sulur tanaman berfungsi sebagai saluran translokasi fotosintat.

\section{METODE}

Penelitian dilaksanakan di kebun percobaan Agro Techno Park Universitas Brawijaya, terletak di Desa Jatikerto, Kecamatan Kromengan, Kabupaten Malang, sejak Januari 2020 sampai Mei 2020. Desain penelitian menggunakan Rancangan Acak Kelompok Faktorial (RAKF) dengan tiga ulangan. Faktor pertama meliputi Kultivar (C) yaitu: $\mathrm{C}_{1}$ (Beta-2), $\mathrm{C}_{2}$ (Kuningan Merah), $\mathrm{C}_{3}$ (BIS OP-61-OP-22). Faktor kedua adalah Defoliasi (D) dengan 3 level, yaitu: $\mathrm{D}_{1}$ (Defoliasi $16 \mathrm{MST}$ ), $\mathrm{D}_{2}$ (Defoliasi $12 \mathrm{MST}$ ), $\mathrm{D}_{3}$ (Defoliasi $8 \mathrm{MST}$ ). Terdapat 27 total unit percobaan. Plot percobaan berukuran $4 \mathrm{~m}$ x 3 $\mathrm{m}$, terdiri 4 gulud, ditanami stek berukuran 25 $\mathrm{cm}$, dengan jarak tanam dalam baris (gulud) $25 \mathrm{~cm}$, sehingga terdapat $48 \mathrm{stek} / \mathrm{plot}^{-1}$, total stek digunakan sebanyak 1.296 stek. Masingmasing plot diberikan pupuk kandang 10 ton.ha ${ }^{-1}$. Pupuk dasar 300 kg NPK Ponska.ha 1 (15:15:15), diberikan dua kali, pertama sebanyak 1/3 bagian pada tanaman berumur 7 hari setelah tanam (HST) dan kedua sisanya pada umur 1,5 bulan setelah tanam (BST). Rasio total bobot kering akar tanaman merambat (F/R) untuk mengklasifikasikan jenis ubi jalar: (a) hijauan (R/F $0 \pm 1)$, (b) tujuan ganda rendah $(\mathrm{R} / \mathrm{F}>1 \pm 1,5)$, (c) tujuan ganda tinggi $(\mathrm{R} / \mathrm{F}>1,5 \pm 2,0)$, (d) produksi akar rendah $(\mathrm{R} / \mathrm{F}>2,0 \pm 3,0)$, dan (e) produksi akar tinggi (R/F > 3,0) (Fuller, 2004).

\section{Parameter}

Perhitungan nilai Relative Growth Rate (RGR), dan Unit Leaf Rate (ULR') :

$$
\begin{gathered}
\mathrm{RGR}=\frac{\left(\ln \mathrm{W}^{2}-\ln \mathrm{W}_{1}\right)}{\left(\mathrm{T}_{2}-\mathrm{T}_{1}\right)} \\
\mathrm{ULR}^{\prime}=\frac{\left(\mathrm{W}_{2}-\mathrm{W}_{1}\right)\left(\ln \mathrm{LD}_{2}-\ln \mathrm{LD}_{1}\right)}{\left(\mathrm{LD}_{2}-\mathrm{LD}_{1}\right)\left(\mathrm{T}_{2}-\mathrm{T}_{1}\right)}
\end{gathered}
$$

Peubah lainnya meliputi : R/F rasio, kriteria umbi dan hijauan. Analisis data didasarkan pada metode (Tes uji F) taraf 5\% menggunakan RAK. Jika data yang diperoleh secara signifikan, kemudian dilanjutkan dengan tes LSD pada tingkat 5\% untuk menentukan perbedaan antar perlakuan.

\section{HASIL DAN PEMBAHASAN}

\section{Analisis Tanah}

Hasil analisis tanah di Agro Techno Park Universitas Brawijaya menunjukkan jenis tanah berupa tanah Alfisol berstatus masam dengan kandungan fraksi pasir $21 \%$, debu $17 \%$ dan liat $62 \%$, berada pada ketinggian 352 $\mathrm{m}$ dpl, termasuk kriteria lahan kering. Lebih jelasnya hasil analisa tanah dapat di lihat pada Tabel 1.

Tanah masam dan perkembangan tanah masam merupakan hal umum di daerah tropis. Bahan Induk yang masam akan menghasilkan tanah-tanah Masam. Disamping itu terdapat faktor-faktor lain yang juga dapat mendorong perkembangan tanah masam yaitu : tingkat pelapukan, curah hujan dan intensitas penggunaan lahan. Makin tinggi tingkat pelapukan, semakin tinggi curah hujan dan makin intensif lahan pertanian digunakan semakin besar kemungkinan berkembangnya tanah-tanah masam. Ketidaksuburan tanah masam daerah tropis, pada umumnya, 
disamping oleh faktor kemasaman tanah juga disebabkan $\mathrm{P}$ rendah dan daya fiksasi fosfor yang tinggi, keracunan tanaman akibat kandungan Al, Fe, Mn yang tinggi, Kapasitas Tukar Kation (KTK) rendah, Kejenuhan Basah (KB) terutama $\mathrm{Ca}$ dan $\mathrm{Mg}$ rendah, dan bahan organik rendah. $\mathrm{pH}$ tanah merupakan salah satu dari sifat tanah yang paling banyak diamati, karena sifat tersebut mempunyai hubungan dengan sifat-sifat kesuburan tanah yang lain (KTK, Kesuburan Tanah, KB dan sebagainya). $\mathrm{pH}$ mempunyai korelasi dengan kandungan $\mathrm{Al}$ dalam tanah Al-dd dan kejenuhan Al. Hasil analisa tanah didapat $\mathrm{pH}$ $\mathrm{KCl}$ (4.7), lebih rendah dari $\mathrm{pH} \mathrm{H}_{2} \mathrm{O}$ (5.1), artinya muatan tanah didominasi oleh muatan negatif dimungkinkan dapat mempengaruhi pertumbuhan ubijalar.

Tabel 1. Hasil analisa sampel tanah di lahan penelitian

\begin{tabular}{llll}
\hline No. & Sifat Tanah & Hasil Pengukuran & Kriteria (Balittanah, 2009) \\
\hline 1. & $\mathrm{pH} 1: 1\left(\mathrm{H}_{2} \mathrm{O}\right)$ & 5,1 & Masam \\
2. & $\mathrm{pH} 1: 1(\mathrm{KCL} 1 \mathrm{~N})$ & 4,7 & Masam \\
3. & C-organik $(\%)$ & 0,68 & Sangat rendah \\
4. & N-total $(\%)$ & 0,09 & Sangat rendah \\
5. & $\mathrm{C} / \mathrm{N}$ & 7 & Rendah \\
6. & $\mathrm{P}-\mathrm{Bray} 1\left(\mathrm{mg} / \mathrm{kg}^{-1}\right)$ & 1,51 & Sangat rendah \\
7. & $\mathrm{K}(\mathrm{me} / 100 \mathrm{~g})$ & 1,04 & Sangat tinggi \\
8. & $\mathrm{Na}(\mathrm{me} / 100 \mathrm{~g})$ & 0,65 & Sedang \\
9 & $\mathrm{Ca}(\mathrm{me} / 100 \mathrm{~g})$ & 5,17 & Rendah \\
10. & $\mathrm{Mg}(\mathrm{me} / 100 \mathrm{~g})$ & 0,47 & Rendah \\
11. & $\mathrm{KTK}(\mathrm{me} / 100 \mathrm{~g})$ & 18,83 & Sedang \\
12. & Jumlah Basa & 7,33 & Sangat rendah \\
13. & KB $(\%)$ & 39 & Rendah \\
\hline
\end{tabular}

Sumber : Laboratorium Kimia Tanah, Fakultas Pertanian Universitas Brawijaya. 2020

\section{Nilai RGR dan ULR'}

Nilai RGR berhubungan dengan ULR', harga RGR yang tinggi diikuti dengan harga ULR' yang besar, ini dapat dipahami bahwa pertambahan bahan baru tanaman berhubungan dengan kemampuan tanaman melakukan fotosintesa sehingga penambahan bahan baru yang dinyataknan persatuan bahan awal (RGR) akan proporsional dengan penambahan bahan baru tanaman persatuan luas daun awal. Dijelaskan Sitompul (2015) bahwa perbedaaan dalam produksi biomassa tanaman dapat disebabkan kemampuan daun menghasilkan karbohidrat melalui prosses fotosintesa. Kemampuan suatu luasan daun menghasilkan biomassa dinyatakan ULR' yang sering disimbolkan dengan $E$ atau dinyatakan dengan NAR. Nilai RGR (mg.g${ }^{1}$.hari ${ }^{-1}$ ) dan ULR' (mg.cm ${ }^{-2}$ ) pada tanaman. Nilai yang didapat lebih tinggi pada kultivar Beta-2 pada RGR (8-4 MST) sebesar $71 \mathrm{mg} \cdot \mathrm{g}^{-}$ ${ }^{1}$.hari ${ }^{-1}$, RGR (12-8 MST) sebesar 56 mg.g
${ }^{1}$.hari ${ }^{-1}$, dan RGR (16-12 MST) sebesar 24 mg. $\mathrm{g}^{-1}$.hari ${ }^{-1}$. Nilai kultivar BIS OP-61-OP-22 terendah pada ULR' (4-8 MST) sebesar 9 mg.cm², ULR' (8-12 MST) sebesar 55 mg.cm 2, dan ULR' (12-16 MST) sebesar 3 mg.cm² . Untuk lebih jelasnya, dapat dilihat pada Tabel 2.

Tanaman ubi jalar, cenderung bersaing dengan bagian lain untuk akumulasi bahan kering. Ini menjelaskan hubungan antara panjang dan total hasil umbi. Tingkat RGR mempengaruhi produksi bahan kering dan akumulasi termasuk jumlah, ukuran dan berat umbi. ULR' adalah tingkat fotosintesis per unit luas daun. Komponen pertama disebut LAR dan menunjukkan seberapa banyak luas daun yang ada per unit total massa tanaman. Komponen kedua adalah ULR', yang juga disebut NAR, meskipun peningkatan ukuran tanaman lebih kurang sebanding dengan massa tanaman. 
Tabel 2. Nilai RGR (8-4 MST, 12-8 MST, 16-12 MST), dan nilai URL' (4-8 MST, 8-12 MST, 16-12 MST.

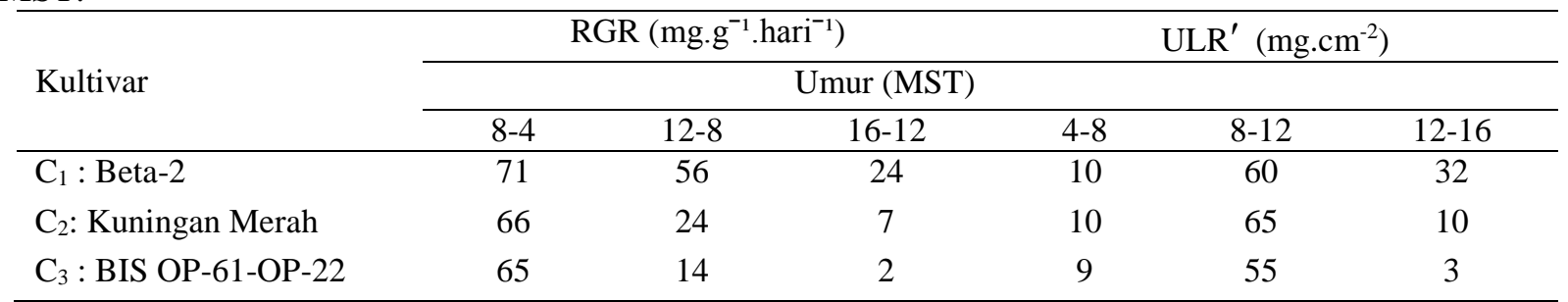

Dalam beberapa hal, tingkat pertumbuhan tanaman bervariasi akibat perubahan intensitas cahaya, dan perbedaan dalam integral cahaya. Pada malam hari, tanaman akan melakukan respirasi dan bahkan kehilangan biomassa. Selama jangka waktu yang lebih lama, RGR umumnya menurun karena beberapa alasan. Pertama, daun yang baru terbentuk di bagian atas tanaman mulai menaungi daun yang lebih rendah, dan oleh karena itu, fotosintesis rata-rata per area unit akan turun, dan begitu juga ULR'. Kedua, biomassa non-fotosintesis, terutama batang, akan meningkat dengan ukuran tanaman. RGR menurun dengan peningkatan ukuran sebagian karena alokasi bahan struktural di batang yang diperlukan untuk menahan daun di kanopi. Tingkat pertumbuhan tanaman akan melambat jika total biomassa meningkat tetapi nilai LAR menurun, meskipun proses fotosintesis aktif terjadi pada daun. Pendekatan lain yang dapat digunakan adalah dengan memisahkan efek ukuran dari perbedaaan pertumbuhan secara intrinsik matematis dalam satuan nilai mg.g${ }^{1}$.hari ${ }^{-1}$. Rentang normal untuk spesies tanaman muda yaitu antara 50-350 mg. $\mathrm{g}^{-1}$.hari ${ }^{-1}$, sedangkan bibit pohon rentang nilainya berkisar antara $10-100 \mathrm{mg} \cdot \mathrm{g}^{-1} \cdot$ hari $^{-1}$. Rincian rasio R/F dan kreteria umbi, dapat dilihat pada Tabel 3 di bawah ini.

Tabel 3. Anova rasio R/F dan kriteria umbi pada kultivar dengan defoliasi umur 16 MST

\begin{tabular}{lcccccc}
\hline \multirow{2}{*}{ SK } & \multirow{2}{*}{ df } & \multicolumn{3}{c}{ KT } & \multicolumn{2}{c}{ F table } \\
\cline { 3 - 7 } & & Ratio R/F & Umbi Besar & Umbi Sedang & Umbi Kecil & $5 \%$ \\
\hline Ulangan & 2 & 1,12 & 1,07 & 1,86 & 1,43 & 3,63 \\
Perlakuan & 8 & $10,06^{* *}$ & $16,14^{* *}$ & $4,14^{* *}$ & 2,47 & 2,59 \\
Kultivar (C) & 2 & $39,30^{* *}$ & $49,84^{* *}$ & $13,56^{* *}$ & $8,15^{* *}$ & 3,63 \\
Defoliasi (D) & 2 & 0,27 & $9,39^{* *}$ & 0,72 & 1,54 & 3,63 \\
Interaksi C*D & 4 & 0,33 & 2,67 & 1,13 & 0,09 & 3,01 \\
Galat & 16 & & & & & \\
Total & 26 & & & & & \\
\hline
\end{tabular}

Rerata hijauan segar yang dihasilkan $\mathrm{C}_{2}$ : (Kuningan Merah) sebesar 43,60 kg.plot ${ }^{-1}, \mathrm{C}_{3}$ (BIS OP-61-OP-22) sebesar 21,82 kg.plot ${ }^{-1}$ dan $\mathrm{C}_{1}$ (Beta-2) sebesar 27,94 kg.plot ${ }^{-1}$. Waktu defoliasi 16 MST menghasilkan 37,03 kg.plot ${ }^{-}$ 1 berbeda dengan waktu defoliasi umur 12 MST dan 8 MST (Tabel 4). Menurut Widaryanto dan Saitama (2017) hasil varietas ubi jalar pada percobaan menunjukkan korelasi negatif dengan luas daun dan LAI, di mana untuk mencapai produktivitas tinggi, nilai LAI rendah. Perlakuan pemangkasan menurunkan hasil pati dan penurunannya bervariasi antar kultivar, pemangkasan 2-3 kali sejak umur 80 HST dapat menurunkan hasil pati lebih dari 50\% (Indawan et al., 2020). 
Tabel 4. Pengaruh Utama, Pengaruh Tunggal dan Kultivar (C) dan Waktu Defoliasi (D) berat hijauan segar (kg/plots) Umur 16 MST

\begin{tabular}{lcccc}
\hline Pengaruh Tunggal (D) & \multicolumn{3}{c}{ Pengaruh Tunggal (C) } & Pengaruh Utama (D) \\
\cline { 2 - 4 } & $\mathrm{C}_{1}$ & $\mathrm{C}_{2}$ & $\mathrm{C}_{3}$ & \\
\hline $\mathrm{D}_{1}: 16$ MST & 27,67 & 50,73 & 32,70 & $37,03 \mathrm{a}$ \\
$\mathrm{D}_{2}: 12$ MST & 21,10 & 44,50 & 29,30 & $31,63 \mathrm{~b}$ \\
$\mathrm{D}_{3}: 8$ MST & 16,70 & 35,57 & 21,83 & $24,70 \mathrm{c}$ \\
Pengaruh Utama (C) & $21,82 \mathrm{c}$ & $43,60 \mathrm{a}$ & $27,94 \mathrm{~b}$ & 31,12 \\
\hline
\end{tabular}

Keterangan: Nilai rata-rata dalam kolom yang sama diikuti oleh huruf yang sama tidak berbeda secara signifikan (tingkat 0.05) menurut tes LSD.

Rerata kriteria untuk umbi besar $\mathrm{C}_{3}$ : (BIS OP-61-OP-22) total 7,54 kg.plot ${ }^{-1}$, tidak berbeda dengan $\mathrm{C}_{2}$ (Kuningan Merah) total 4,26 kg.plot ${ }^{-1}$ dan $\mathrm{C}_{1}$ (Beta-2) total 4,26 kg. plot $^{-1}$. Waktu defoliasi 16 MST berbeda dengan waktu defoliasi 12 MST (3,45 kg.plot $\left.{ }^{1}\right)$ dan 8 MST (1,92 kg.plot $\left.{ }^{-1}\right)$. Rinciannya Umbi Besar dapat dilihat pada Tabel 5.

Tabel 5. Pengaruh Kultivar (C) dan Waktu Defoliasi (D) terhadap Umbi Besar (kg/plot) 16 MST

\begin{tabular}{llccc}
\hline \multicolumn{1}{c}{ Pengaruh Tunggal (D) } & \multicolumn{3}{c}{ Pengaruh Tunggal (C) } & Pengaruh Utama (D) \\
\cline { 2 - 4 } & $\mathrm{C}_{1}$ & $\mathrm{C}_{2}$ & $\mathrm{C}_{3}$ & \\
\hline $\mathrm{D}_{1}: 16$ MST & 7,83 & 9,74 & 14,49 & $10,69 \mathrm{a}$ \\
$\mathrm{D}_{2}: 12$ MST & 3,79 & 1,78 & 4,79 & $3,45 \mathrm{~b}$ \\
$\mathrm{D}_{3}:$ 8 MST & 1,17 & 1,26 & 3,33 & $1,92 \mathrm{~b}$ \\
Pengaruh Utama (C) & 4,26 & 4,26 & 7,54 & 5,35 \\
\hline
\end{tabular}

Keterangan: Nilai rata-rata dalam kolom yang sama diikuti oleh huruf yang sama tidak berbeda secara signifikan (tingkat 0.05) menurut tes LSD.

Kriteria Umbi Sedang $\mathrm{C}_{3}$ : (BIS OP-61OP-22) total 2,77 kg.plot ${ }^{-1}$ tidak berbeda dengan $\mathrm{C}_{2}$ (Kuningan Merah) total 2,68 kg.plot ${ }^{-1}$ dan $\mathrm{C}_{1}$ (Beta-2) total 1,91 kg.plot ${ }^{-1}$. Waktu defoliasi 16 MST menghasilkan 4,24 kg.plot ${ }^{-1}$ berbeda dari waktu defoliasi $12 \mathrm{MST}$ yaitu sebesar $1,72 \mathrm{~kg}_{\text {.plot }}{ }^{-1}$ dan $8 \mathrm{MST}$ sebesar 1,41 kg.plot ${ }^{-1}$. Rinciannya Umbi Sedang dapat dilihat di Tabel 6.

Tabel 6. Pengaruh Kultivar (C) dan Waktu Defoliasi (D) terhadap Umbi Sedang (kg.plot ${ }^{-1}$ ) $16 \mathrm{MST}^{\mathrm{M}}$

\begin{tabular}{llllc}
\hline Pengaruh Tunggal (D) & \multicolumn{3}{c}{ Pengaruh Tunggal (C) } & Pengaruh Utama (D) \\
\cline { 2 - 4 } & $\mathrm{C}_{1}$ & $\mathrm{C}_{2}$ & $\mathrm{C}_{3}$ & \\
\hline $\mathrm{D}_{1}: 16$ MST & 2,81 & 5,33 & 4,57 & $4,24 \mathrm{a}$ \\
$\mathrm{D}_{2}: 12 \mathrm{MST}$ & 1,96 & 1,16 & 2,04 & $1,72 \mathrm{~b}$ \\
$\mathrm{D}_{3}: 8$ MST & 0,97 & 1,54 & 1,71 & $1,41 \mathrm{~b}$ \\
Pengaruh Utama (C) & 1,91 & 2,68 & 2,77 & 2,45 \\
\hline
\end{tabular}

Keterangan: Nilai rata-rata dalam kolom yang sama diikuti oleh huruf yang sama tidak berbeda secara signifikan (tingkat 0,05 ) menurut tes LSD.

Rerata kriteria untuk Umbi Kecil C $\mathrm{C}_{3}$ : (BIS OP-61-OP-22) total 1,49 kg.plot ${ }^{-1}$ tidak berbeda dengan $\mathrm{C}_{2}$ (Kuningan Merah) total 1,30 kg.plot ${ }^{-1}$ dan $\mathrm{C}_{1}$ (Beta-2) total 1,25 kg.plot ${ }^{-1}$. Waktu defoliasi 16 MST menghasilkan 1,72 kg.plot ${ }^{-1}$ berbeda dengan waktu defoliasi 12 MST sebesar 1,47 kg.plot ${ }^{-1}$ dan 8 MST sebesar 0,85 kg.plot ${ }^{-1}$. Rinciannya Umbi Kecil dapat dilihat di Tabel 7.

Wahyuni dan Wargiono (2012) menyatakan bahwa tanaman ubi jalar umumnya terdiri dari dua bagian utama, yaitu organ tanaman yang berada di atas tanah berupa batang dan cabang utama, daun, bunga 
dan biji, serta organ tanaman yang berada di dalam tanah berupa akar dan ubi. Tanaman yang terlalu subur perlu dipangkas karena tanaman yang daunnya terlalu subur akan mengurangi hasil umbi. Pemangkasan bertujuan untuk membentuk arsitektur daun yang lebih kompak dan jarak yang lebih pendek dari sumber sehingga fotosintesis lebih efektif dan translokasi lebih cepat. Kehadiran daun berbayang, karena kanopi yang terlalu subur dapat mengurangi efektivitas fungsi daun sebagai produsen fotosintesis.

Tabel 7. Pengaruh Kultivar (C) dan Waktu Defoliasi (D) terhadap Umbi Kecil (kg.plot ${ }^{-1}$ ) 16 MST

\begin{tabular}{llllc}
\hline \multirow{2}{*}{ Pengaruh Tunggal (D) } & \multicolumn{3}{c}{ Pengaruh Tunggal (C) } & Pengaruh Utama (D) \\
\cline { 2 - 4 } & $\mathrm{C}_{1}$ & $\mathrm{C}_{2}$ & $\mathrm{C}_{3}$ & \\
\hline $\mathrm{D}_{1}: 16$ MST & 1,57 & 1,71 & 1,87 & $1,72 \mathrm{a}$ \\
$\mathrm{D}_{2}: 12$ MST & 1,51 & 1,52 & 1,37 & $1,47 \mathrm{~b}$ \\
$\mathrm{D}_{3}: 8$ MST & 0,81 & 0,51 & 1,24 & $0,85 \mathrm{~b}$ \\
Pengaruh Utama (C) & 1,30 & 1,25 & 1,49 & 1,35 \\
\hline
\end{tabular}

Keterangan: Nilai rata-rata dalam kolom yang sama diikuti oleh huruf yang sama tidak berbeda secara signifikan (tingkat 0.05) menurut tes LSD

\section{Komponen Pertumbuhan}

Laju peningkatan volume kultivar ubi jalar meningkat sejak awal pertumbuhan dan belum ada persaingan di antara tanaman untuk mendapatkan sinar matahari, air, nutrisi dan ruang untuk tumbuh sehingga kebutuhan faktor pertumbuhan tanaman masih terpenuhi dengan baik. Setiap kultivar tanaman ubi jalar memiliki nilai RGR yang berbeda, karena ditentukan oleh bentuk kanopi daun. Nilai RGR tertinggi kultivar Beta-2 (8-4) sebesar 71 mg.g.g ${ }^{-1}$.hari ${ }^{-1}$, RGR (12-8) sebesar 56 mg.g${ }^{1}$.hari-1, dan RGR (16-12) sebesar $24 \mathrm{mg} \cdot \mathrm{g}^{-}$ ${ }^{1}$.hari ${ }^{-1}$, hal ini disebabkan oleh fakta bahwa sebagian besar daun berbayang terjadi secara alami, terutama pada umur 16 MST, sehingga tidak optimal dalam melakukan fotosintesis. RGR akan mempengaruhi peningkatan kapasitas sumber yang dapat memenuhi kebutuhan kapasitas sehingga akan mempengaruhi indeks hasil. Menurut Liu et al (2017) bahwa daun adalah organ fotosintesis utama pada tanaman, di mana proses mengubah energi cahaya menjadi energi kimia terjadi dan mengumpulkan energi dalam bentuk bahan kering. Selanjutnya (Winardi dan Sitepu, 2017; Gong et al, 2013) menyatakan bahwa luas daun tanaman menunjukkan mekanisme intersepsi radiasi cahaya, transpirasi, pertumbuhan dan hasil. Pertumbuhan adalah hasil dari akumulasi dan alokasi sumber daya, sementara pengembangan diwujudkan sebagai interaksi antara sumber daya non-kumulatif seperti suhu, periode foto dan kualitas cahaya (Sadras et al., 2016).

\section{Komponen Produksi}

NAR adalah efisiensi pengukuran fotosintesis pada daun dalam penggunaan radiasi matahari serta nutrisi yang ada di zona iklim mikro di sekitar tanaman. Hal ini terjadi selama proses fotosintesis, sehingga lebih banyak energi yang dihasilkan untuk pertumbuhan tanaman. NAR ditentukan oleh kondisi lingkungan, terutama pada ubi jalar yang tumbuh dengan kondisi kelembaban tinggi, hal ini akan memacu pertumbuhan organ daun tanaman. Kultivar merespon secara berbeda tergantung pada kondisi tanah dan lingkungan di mana lokasi dibudidayakan, di tanah dengan kapasitas memegang air rendah, genotipe dengan efisiensi tutupan tanah yang lebih tinggi menunjukkan adaptasi utama dan akumulasi biomassa akar. Kriteria untuk umbi Besar, kultivar Beta-2 menghasilkan: 17,78 umbi, kultivar Kuningan Merah menghasilkan: 14,22 umbi dan kultivar BIS OP 61-OP-22 menghasilkan: 51,22 umbi. Kriteria untuk umbi Sedang, kultivar Beta-2 menghasilkan: 23,11 umbi, kultivar Kuningan Merah menghasilkan: 19,56 umbi dan BIS OP 
61-OP-22 kultivar menghasilkan: 44,33 umbi. Kriteria untuk umbi Kecil, kultivar Beta-2 menghasilkan: 45,56 umbi, Kuningan Merah: 35,89 umbi dan BIS OP 61-OP-22: 35.89 umbi. Nilai ULR' Kuningan Merah (4 - 8 MST) sebesar 10 mg.cm ${ }^{-2}$ dan (8 - 12 MST) sebesar 65 mg.cm ${ }^{-2}$ dan Beta-2 ULR' (12 - 16 MST) sebesar $32 \mathrm{mg} . \mathrm{cm}^{-2}$. Hijauan atau brangkasan yang didapat dari kultivar Kuningan Merah sebanyak (43,60 kg.plot ${ }^{-1}$ ). Penelitian terkait defoliasi kanopi ubi jalar menunjukkan peningkatan pertumbuhan kanopi tanaman yang signifikan tanpa mengurangi kualitas umbi yang dihasilkan (Novianti dan Setiawan, 2018). Pertimbangkan keseimbangan pertumbuhan umbi, kemampuan tanaman untuk pulih, dan masih mempertahankan tingkat produksi umbi (Wawo et al., 2019). Penelitian ini menggunakan NPK Phonska (15:15:15) sebanyak $300 \mathrm{~kg} \cdot \mathrm{ha}^{-1}$, menyediakan $45 \mathrm{~kg} \mathrm{~N}$, $45 \mathrm{~kg} \mathrm{P}_{2} \mathrm{O}_{5}$ dan $45 \mathrm{~kg} \mathrm{~K} \mathrm{~K}_{2} \mathrm{O}$. Unsur $\mathrm{N}$ diserap oleh tanaman ubi jalar melalui aliran massa berupa $\mathrm{NH}_{4}$, dan $\mathrm{NO}_{3}{ }^{-}$, sedangkan $\mathrm{P}$ dan $\mathrm{K}$, diambil melalui proses difusi dalam bentuk $\mathrm{H}_{2} \mathrm{PO}_{4}{ }^{-}, \mathrm{HPO}_{4}{ }^{-}$dan K. Kontribusi jumlah N yang tersedia dari tanah $(0,09 \%=2,16 \mathrm{~N})$, sedangkan dari pupuk kandang $(0,53 \%=0,63$ $\mathrm{N})$ dan dari Phonska $(15 \%=0,54 \mathrm{~N})$, jumlah $\mathrm{P}$ yang tersedia dari tanah $(0,76 \%=18,24$ $\left.\mathrm{P}_{2} \mathrm{O}_{5}\right)$, sedangkan dari pupuk kandang $\left(0,35 \%=0,04 \mathrm{P}_{2} \mathrm{O}_{5}\right)$ dan dari Phonska (15\% $\left.=0,54 \mathrm{P}_{2} \mathrm{O}_{5}\right)$, jumlah $\mathrm{K}$ yang tersedia dari tanah $\left(2,61 \%=62,64 \mathrm{~K}_{2} \mathrm{O}\right)$, sedangkan dari pupuk kandang $\left(0,41 \%=0,05 \mathrm{~K}_{2} \mathrm{O}\right)$ dan dari Ponska $\left(15 \%=0,54 \mathrm{~K}_{2} \mathrm{O}\right)$. Nutrisi $\mathrm{N}$ menjadi faktor pembatas, bahwa jumlah $\mathrm{N}$ yang tersedia adalah: $2,16+0,63+0,54=3,33 \mathrm{~N}$. Selanjutnya, untuk menghasilkan 20 ton.ha ${ }^{-1}$, ketiga nutrisi tersebut harus tersedia sebanyak 4,6 - $151 \mathrm{~kg} \mathrm{~N}, 9,4$ - 52,00 kg $\mathrm{P}_{2} \mathrm{O}_{5}$ dan 31,8 $229,40 \mathrm{~kg} \mathrm{~K}_{2} \mathrm{O}$ ha $^{-1}$ (Indawan et al., 2018). Sejalan dengan pendapat Zhang et al., (2017) bahwa setiap ton hasil ubi jalar membutuhkan jumlah nutrisi $\mathrm{N}, \mathrm{P}_{2} \mathrm{O}_{5}$ dan $\mathrm{K}_{2} \mathrm{O}$ berkisar 2,30 - 7,58 kg N, 0,47 - 2,64 kg $\mathrm{P}_{2} \mathrm{O}_{5}$ dan 1,59 $11,47 \mathrm{~kg} \mathrm{~K}_{2} \mathrm{O}$. Faktor penyebab lainnya dapat dimungkinkan karena curah hujan tinggi sebanyak: $295 \mathrm{~mm} \cdot$ bulan $^{-1}$, dengan suhu ratarata $24,6^{\circ} \mathrm{C}$ dan 5,75 jam paparan sinar matahari

\section{SIMPULAN}

Nilai RGR yang tinggi diikuti oleh harga ULR' yang besar, yang berarti perimbangan penambahan bahan tanaman baru terkait dengan kemampuan tanaman untuk melakukan fotosintesis. Nilai kultivar Beta-2 RGR pada umur 8-4 MST sebesar $71 \mathrm{mg} . \mathrm{g}$ ${ }^{1}$.hari ${ }^{-1}$, Kuningan Merah ULR' $(8$ - 12) sebesar 65 mg. $\mathrm{cm}^{-2}$. Kultivar BIS OP-61-OP22 menghasilkan kriteria umbi Besar (51,22 umbi) dan kriteria umbi Sedang (44,33 umbi). Rasio R/F pada kultivar BIS OP-61-OP-22 menghasilkan hasil umbi tinggi, sementara Beta-2 dan Kuningan Merah memproduksi akar tinggi.

\section{UCAPAN TERIMA KASIH}

Penulis mengucapkan terima kasih kepada Direktorat Jenderal Penguatan Penelitian dan Pengembangan, Kementerian Riset, Teknologi dan Pendidikan Tinggi dalam mendanai penelitian ini. Ucapan yang sama disampaikan atas dukungan teknis dari Agrotechnopark Universitas Brawijaya dan Balitkabi Malang, atas izin lokasi dan bibit tanaman yang digunakan.

\section{DAFTAR PUSTAKA}

Fuller, M. F. (2004). The Encyclopedia of farm animal nutrition. CABI publishing.

Gibberson, D. (2011). The Effect of Defoliation on the Quality of Sweet Potato Tubers. Asian J. Agric. Res. 5:300-305.

Gong, Y., J. Zhang, X. Guo, X. Wan, Z. Liang, H. CJ, M. \& Jiang. (2013). Identification and characterization of PtDGAT2B, an acyltransferase of the DGAT2 acylcoenzyme A: diacylglycerol acyltransferase family in the diatom Phaeodactylum tricornutum. FEBS Lett. 587:481-487.

Indawan, E., S.U. Lestari, \& N. Thiasari. (2018). Sweet potato response to biochar application on sub-optimal dry land. J. Degrad. Min. Lands Manag. 5:1133-1139. 
Indawan, E., S.U. Lestari, N. Thiasari, \& P. Sasongko. (2020). The Pruning Effect on the Storage Root Yield and Starch Content of Sweet Potato Clones Planted at Dry Land. Caraka Tani J. Sustain. Agric. 35:289-298.

Liu, Z., Y. Zhu., F. Li., \& G. Jin. (2017). Nondestructively predicting leaf area, leaf mass and specific leaf area based on a linear mixed-effect model for broadleaf species. Ecol. Indic. 78:340-350.

Novianti, D., \& A. Setiawan. (2018). Pengaruh Pemangkasan Pucuk dan Jarak Tanam terhadap Pertumbuhan dan Produksi Bibit Ubi Jalar (Ipomoea batatas L.). Bul. Agrohorti 6:143.

Rahmiana, E.A., S.Y. tiasmoro., \& N.E. Suminarti. (2015). Pembalikan Batang pada Pertumbuhan dan Hasil Tanaman Ubi Jalar (Ipomoea batatas L) Varietas Madu Oranye. J. Produksi Tanam. 3 (2): 126-134.

Sadras, V.O., F.J. Villalobos, \& E. Fereres. (2016). Crop development and growth. Principles of Agronomy for Sustainable Agriculture. Springer, Cham, pp. 141-158.

Sitompul, S. M. (2015). Analisa Pertumbuhan Tanaman. Penerbit UB Press. Malang.
Suminarti, N.E., \& R. Novriani. (2017). Pengaruh Defoliasi dan Posisi Penanaman Stek Batang pada Pertumbuhan dan Hasil Tanaman Ubi Jalar (Ipomoea batatas L.) Lam. Var. Sari. J. Biodjati 2 (1): 21-29.

Wahyuni, T.S., \& J. Wargiono. (2012). Morfologi dan Anatomi Tanaman. Prosiding. Puslitbangtan. Balitbangtan, Balitkabi, Malang.37-56.

Wawo, A.H., P. Lestari, \& N. Setyowati. (2019). Respon Pertumbuhan dan Produksi Empat Kultivar Ubi Jalar (Ipomea batatas L . Poir) Dataran Tinggi Papua Terhadap Pemangkasan Pucuk. J. Biota. 4 (3): 94 103.

Widaryanto, E., \& A. Saitama. (2017). Analysis of plant growth of ten varieties of sweet potato (ipomoea batatas L.) cultivated in rainy season. Asian J. Plant Sci. 16:193-199.

Winardi, R.R., \& F.R. Sitepu. (2017). Respon Campuran Media Tanam dan Perlakuan Fisik Terhadap Laju Pertumbuhan dan Produksi Pada Tanaman Ubi Jalar (Ipomea batatas L). J. Agroteknosains 1 (1):46-59.

Zhang, Y.C., J.D. Wang, Y.X. Shi, \& D.F. Ma. (2017). Nutrient Management for High Efficiency Sweet Potato Production. Phytonutritional Improvement of Crops. 471-497. 